\title{
Improving reforms of higher economics education in Ukraine: foreign experience
}

\author{
O. A. Borysenko \\ Institute of Higher Education of the National Academy of Educational Sciences of Ukraine, Taras Shevchenko National University of Kyiv \\ Corresponding author. E-mail: o.borysenkotsu@gmail.com
}

Paper received 20.10.18; Accepted for publication 26.10.18.

\section{https://doi.org/10.31174/SEND-PP2018-181VI75-02}

\begin{abstract}
The article analyzes the experience of the countries of the European Union and the USA in reforming higher education. The primary task of economic education policy is to achieve high quality of education, its relevance to current and future economic needs
\end{abstract} personality and state. The article describes a number of factors affecting the deterioration.

Keywords: education quality, higher economic education, modernization higher education, improving higher economic education reform.

Introduction. Accelerating the economic development, improving the legislative framework and tax policy in Ukraine are intensifying the role of higher economic education. The state of modern economics education in Ukraine is determined by the necessity the transition to the new foundations of the growth of economic knowledge, formation of the modern economic views that will contribute the progress of humanization and socialization of social processes, national identity itself. The system of higher education in Ukraine is able to compete with the education systems of the developed countries. The state is carrying out a comprehensive modernization of education with the creation of a mechanism for its effective use.

Literature Review. The conducted analysis of scientific achievements testifies to the absence of fundamental systematic studies of economic education in Ukraine. However, it should be emphasized that such Ukrainian economists as G. Bashnyanin, V. Basilievich, Z.Vatamanyuk, E.Vorobiev, A.Galchinsky, V.Geyets, A.Gritsenko, I.Malyi, Yu. Nikolenko, S. Panchyshyn, G.Stebliy, V.Tarasevich, I.Tivonchuk, A.Chukhno and others were made the significant impact in a research in the field of higher economics education. The current trends and tendencies in economic education are investigated in the works of foreign researchers: A. Ibukun, G.Becker, W.E.Becker, C. Clotfelter, J. Geraint, R.K. Toutkoushian, M.B.Paulsen, Th.Assan ant others.

Aim. The aim is to highlight the problems of modern higher economics education in Ukraine and to analyze foreign experience in reforming it.

Methods. To disclose these topic, descriptive and logical methods were used; for collection and generalization, the methods of induction and deduction, the method of comparison, analysis and synthesis of information were applied.

Results and Discussion. Nowadays our society needs to distinguish two terms: 'Economics of Education' and 'Economic Education' and define the term 'Higher Economics Education', which is not exactly explained in any researches. According to J.B. Babalola, the difference between economics of education and economic education is the dominance of education as a variable in every argument and application of economic principles, laws, and concepts to educational issues [1]. In the scientific Ukrainian literature economics education is considered from two point of views: economics education as a professional training for future economists (vocational and economic); economics education as a set of certain economic knowledge pos- sessed a personality (general economic) [2]. The essential problem of economics of education is how the decision makers will make use of the limited resources at their disposal to best satisfy their unlimited educational wants.

The long-term structural crisis in Ukraine has led to a significant outflow highly skilled staff, which has significantly outrun the Ukrainian economy. Due to the Western scholars' statistics, emigration of one highly qualified specialist is equally to embedding in the economy one million dollars. Over the years of the Ukrainian reformation near $30 \%$ of higher-skilled and able-bodied scientists left the country beyond the country's economy [3, p.314]. There exists also a contradiction between economic education and modern business, which needs practical-oriented specialists. Ability to apply knowledge that increases the competitiveness of the company are especially important for the successful economic activity in current market environment.

The system of higher education in the United States is aimed at determining the professional competence of future economists, which consists of: 1) competence in the field of economic activity (economic thinking, possession of economic analysis methods and designing of economic activity, availability of a systematic understanding of the structure and trends of development of the domestic and world economies, knowledge of the principles of the adoption and implementation of economic and managerial decisions at the micro and macro levels, creation and development of own economic position, etc.); 2) competence in other areas of professional activity (system of knowledge of finance, marketing, audit, international economics, law, management); 3) information competence (effective application of information technologies and related programs); 4) communicative competence (knowledge of business ethics and conflict research) [4]. The advantage of higher economics education in the United States is to provide access to its elements to all those wishing to improve their professional level under the motto "lifelong education". The main feature is the cooperation of educational institutions, production and business.

New economic conditions, together with the phenomenon of democratization of all social life, stimulated the transition to fundamentally new approaches in educational planning and in the implementation of reforms. Many developed countries have begun to create models of the information society. This model was chosen in Poland which is not only located near Ukraine, but also has already be- 
come to provide these reforms at the end of XX century. The deepening of European integration and the increasing influence of globalization processes prove that the experience of Poland has a number of priorities in comparison with other educational models. In the achievement of the success of higher economics education reforms in Poland, the following factors played a decisive role:1) widespread use of legislative tools and means of confrontation with potential opponents of reforms; 2) to reduce the risk of damage from false steps at the initial stage of the planning of the reform, limited experiments were carried out with a subsequent analysis of their results and adjustments to the general scheme, algorithms for the implementation of plans and ways to achieve socially important goals. Among the European practice of quality assurance in higher education with a high level of youth coverage, Poland has used the experience of Finland and the Netherlands, where government authorities have abandoned the detailed inspections, using a system of expanding autonomy.

In Poland, reforms have proven to be more productive, since more accurately projected global changes in labor and trade markets, promising areas of concentration of national resources, more money are involved, and the most recent legislative and democratic model is used.

Usually the quality of higher education in Ukraine, in particular, in the field of economics, was associated only with the content and form of the educational process. Therefore, unfortunately, control over the Ukrainian quality assurance system is still carried out by administrative and command methods, while the European education has already used method of free choice. Modernization of the Ukrainian education is directly related to the implementation of the Bologna Arrangements, its integration into the European Educational Space. In Ukraine an active development of the Bologna process began in the Ministry of Education and Science of Ukraine in order to 'On approval of the Program of Action for the implementation of the provisions Bologna Declaration in the System of Higher Education and Science of Ukraine for 2004-2005 ' of January 23, 2004 No. 49. When Ukraine joined the Bologna in the area of education has been an impetus for the reform of the Ukrainian education in general and the search for ways of internal and external quality assurance in higher education. These processes are reflected in the legal documents, laws, 'Concepts of quality assurance of higher education in Ukraine', 'Concepts of economics education'.

Higher economics education requires modernization of an integrated model of financing education, the elements of which should be such investment sources: multi-channel public funding of higher education, lending to higher education institutions and support for self-financed economic entities, public fund grants, non-governmental organizations, in particular, international. Among the problems characterizing the system of higher economics education in Ukraine is a relatively inefficient mechanism of state financing of the education system. Trends in increasing investment in education and their efficiency are global. Thus, in Germany, education costs account for about $5 \%$ of GDP, Great Britain, France - $6 \%$ of GDP, Italy - $4.3 \%$ of GDP, Greece $-4 \%$ of GDP, Japan $-3,4 \%$ of GDP, Ukraine $5,3 \%$ GDP [5, p.202]. The sphere of higher education occupies a key role in the system of investment in education and science. There is a tendency to reduce the volume of budget financing of the sphere of higher education until now, as a consequence, is the reduction of the state order for the training of specialists of different levels. This tendency of investing in higher educational institutions prompts groups of the latter to actively use extra-budgetary financing instruments budget programs and expansion of entrepreneurial activity of universities. Despite all the problems of investment activity, Ukraine is one of the record holders in terms of the number of citizens with higher education - more than $83 \%$ of the employment age.

Accelerating the processes of Euro-Atlantic integration can be successful only if there are fundamental and very rapid transformations in the system of higher economic education. The Strategy for Socio-Economic Development of Ukraine for the period 2004-2015 [6] defined the strategic directions of economic development: sustainable economic growth, innovative economic development, social reorientation of the economy, integration into the European Union, development of the knowledge economy. At the same time, we should note that the trend towards the development of the knowledge economy is mainly technocratic. The development of higher economics education in Ukraine have a significant slowdown and it can be explained by some factors: the economic crisis, the classical economic theories that consider the economic growth in the context of the four categories (land, labor, capital, technology), not paying attention to human capital. Obtaining economic knowledge through memorizing and repeating the received information, studying what has already been done, and not innovation and modeling the solution of emerging problems is a painful issue in quality assurance of higher education in general.

Despite the active implementation of the main provisions of the credit-module system in higher education institutions, most experts acknowledge that the level of knowledge of students in Ukraine has become much lower, but learning is more difficult, the most universities in Ukraine perceived the Bologna process in their own way, and therefore, used it in their own interests. In the current conditions of the implementation of European integration priorities of Ukraine arises the need for the interaction of education and science with the real economic space, set up of forms and mechanisms of relations with financial, social institutes in favor of solving new market problems - training highly skilled staff in accordance with the needs of the labor market, the implementation of research in modern production.

The main factors that contribute to the deterioration of the quality of education in Ukraine can be divide into internal (related to distorted perceptions and implementation higher educational establishments of the provisions of the credit-module system, which do not contribute to raising the level knowledge of students) and external (related to the state's influence on the education system). The internal factors can be attributed as following: initially, increase the amount of material allocated for self-learning. In fact, more than $50-60 \%$ of the material of the curriculum is given to self-study. Self-study work of students in the most universities of Ukraine, at the beliefs of many experts, was almost the main factor of decline the level of knowledge of students. It consists mainly of writing a syllabus, essays on the Internet, as according to the credit-module 
system, the student's rating score is put on the basis of all the educational achievements and in particular has three components (modules) - lecture, practical and self-study. Given the fact that the assessment is average, the most important value is self-study module, because it is allocated the most academic hours of workload.

According to the accumulation system, scores and exams have lost their role, since the system of "automatic grade" known to the most familiar from the Soviet times was actually legalized, when the best students were presented with ratings without their presence in the exam. The discrepancy of the disciplines that are taught in Ukraine, the European, and also, the prospect of mutual deduction of educational achievements between different educational institutions both inside Ukraine and in Europe. Such measures should be supportive of the mobility of students between higher education institutions within the EU, simplification of student employment opportunities, increase quality of education, taking into account the requirements of time, including market economy and applied knowledge.

Ukraine has concluded numerous intergovernmental international agreements on the mutual recognition of education documents, degrees and academic titles. However, the number of universities of our country, which introduced joint programs and assign nationally recognized degrees in cooperation with higher education in other countries make up only $3 \%$ of the total number of Ukrainian higher education institutions [7].

Autonomy of higher educational institutions, as, for example, in EU and the USA, exist in Ukraine only on paper. In civilized countries the autonomy is determined primarily by the economic independence of institutions from the state, the competitive principles of the existence of a higher school, the combination of the basic principles of existence and the provision of higher education services. In Ukraine, the state serves as the customer of educational services and forms the standard of higher education.

The external factors can be attributed as following: first of all, low volume of financing from the state budget. Public funding of higher education and science in Ukraine is extremely unsatisfactory and does not meet the scale and norms of the laws of Ukraine "On Education" and "On Higher Education". The state loses its leading position on the level of education of citizens, decline the scope and level of the training of academic staff, considerably deteriorate the conditions for the creative work of scientists and teachers [8]. If in the state science accounts for less than $2 \%$ of GDP, destructive processes begin not only in science itself but also in the economy and society. For example, this figure is $3.5 \%$ in Israel, $2.75 \%$ in Japan, $2.05 \%$ in the United States[8]. Therefore, even 1,7\% of the GDP stipulated by the Law of Ukraine "On Science and Scientific and Technical Activities" will not solve the problem.

The unsatisfactory state of research activity of the universities at the current stage is also one of the most important external factor. Nowadays the Ukrainian science, in particular, the science of higher education, is in a critical condition, which not only does not meet the needs of modern high-quality education, but also creates a real threat to the national security of the state.

Unfortunately, there is a low level of innovation education in Ukraine. According to the enormous losses in our science, and therefore in education, the country has little to do on its own at the level of modern "hi-tech". Up to date, only the United States, Japan, some European and other wealthy states are capable of it. An adequate scientific infrastructure created per scientist accounts for 100-200 thousand dollars annually. Europe, as a task, says about an amount of 1 million euros. According to the Ukrainian scientific statistics, one scholar has about 2 thousand dollars annually [8]. Knowledge production is the main source of economic development. Thus, in Norway and Denmark, investment in the knowledge sector is $8.3 \%$ of GDP; in the USA - 5,7\%, in India - 3,5\%. Led behind the developed countries for investment in education, Ukraine reduces its competitiveness. Our country can become competitive only if the raw material economy changes to the knowledge economy. The country's budget is more than half dependent from the raw materials industry. Even in the UAE, such addiction fades; they return to the knowledge economy, which implies the presence of such a carrier of knowledge talented scholars, which grow out of gifted children. The Emirates do not spare money to gifted children and their education (of course, free) at the best elite university of the World [9].

Thus, the primary task of educational policy in the field of economics is the achievement of the modern quality of education, its conformity to actual and perspective economic needs of the individual, society and the state. The share of the specialists who have received higher education in Ukraine in 2010 it was $17.4 \%$, in 2011 it was $28.7 \%$, and in 2018 it was $32.7 \%$. The data indicate that it is about one third of the total graduates.

According to Forbes magazine, there are ten top professions in 2017, specialists involved in risk assessment, calculation of the probability of solving economic problems and making the best decisions. When drawing up the list was taken into account such factors as: annual income, working conditions, demand of the profession employers, stress levels. This list includes the professions of accountant and analyst. According to the Forbes, economics higher education remains one of the most prestigious and popular.

The prestige of higher economic education in Ukraine in comparison with other fields has been preserved due to the influence of the following factors: 1) the need for economists and managers has increased in Ukraine, who possessing new methods of management; 2) a change in the structure of the Ukrainian industry, an increase in the number of nonprofit profile in the field of trade, household services, entertainment and other created new working places, where the experts needed the very economic profile.

The negative tendency in Ukraine is to reduce the number of students in higher education institutions of the III-IV level of accreditation during the last two years due to the deterioration of the demographic situation, unstable political situation, military activity in the East of Ukraine, the desire of the alumnus to receive education abroad. Given the state of the Ukrainian higher education, a common type of Ukraine has the programs for the student exchanges and internships, teachers abroad, which is faster for us to import education services than their exports.

Conclusions. Strategic task of the state educational policy in Ukraine is a competitive existence of the Ukrainian education into the market of world educational services, deepening of international cooperation. Education is the basis of social, political, economic, spiritual and cultural 
development of society. One of the important strategic tasks of higher educational institutions of Ukraine is integration into the European educational and scientific space. The quality of higher economics education depends on the observance of modern world educational standards, adequate financing, favorable conditions for investors and the efficient use of all types of resources involved in the industry.

\section{ЛИТЕРАТУРА}

1. Babalola, J.D. Fundamentals of Economics of Education. Basic Text in Educational Planning. Ibadan, 2003.

2. Дутка Ганна Сучасний стан та перспективи розвитку економічної освіти в Україні //Zeszyty Naukowe PWSZ w Płocku. Nauki Ekonomiczne, 2017, Tom 25(8), C. 125 - 141.

3. Сщенко П.С. Сучасна економіка:навчальний посібник Київ, 2005, 325c.

4. Огнівко Л.В. Професійна підготовка магістрів економічного профілю у вищих закладах США. URL: http://www.nbuv/gov/ua/portal/soc_gum/Znpkhist/2011_3/11ol vnzs.pdf

5. Доклад о развитии человека 2010. Реальное богатство народов: пути к развитию человека. М., 2010, С.202-203.

6. Стратегія соціально-економічного розвитку України на період 2004 - 2015.URL: http://old.niss.gov/book

7. Богачевська I., Карпенко М. Болонський процес в Україні: стан i проблеми реалізації. URL: http:// http://old.niss.gov.ua/Monitor/May08/09.htm

8. Хайнацька Ю.Ю., Гордєєва Т.А. Аналіз фінансування видатків на освіту в Україні. URL: http://intkonf.org/haynatskayuyu-gordeeva-ta-analiz-finansuvannya-vidatkiv-na-osvitu-vukrayini

9. Боголіб Т.М. Розвиток інноваційної економіки і елітна освіта. URL: http://www.disserlib.com

\section{REFERENCES}

1. Babalola, J.D. Fundamentals of Economics of Education. Basic Text in Educational Planning. Ibadan, 2003.

2. Dutka Hanna Current Status and Prospects of Economic Education in Ukraine//Zeszyty Naukowe PWSZ w Płocku. Nauki Ekonomiczne, 2017, Tom 25(8), P. 125 - 141.

3. Yeshchenko P.S. Modern Economics: Textbook. Kyiv, 2005 $325 \mathrm{p}$.

4. Ohnivko L.V. Professional training of Masters of economics in US universities.URL: http://www.nbuv/gov/ua/portal/soc_gum/Znpkhist/2011_3/11ol vnzs.pdf

5. Human Development Report 2010. The real wealth of peoples: the path to human development. M., 2010, p.202-203.

6. Strategy of socio-economic development of Ukraine for the period 2004 - 2015. URL: http://old.niss.gov/book

7. Bogachevskaya I., Karpenko M. Bologna process in Ukraine: the state and problems of realization. URL: http:// http://old.niss.gov.ua/Monitor/May08/09.htm

8. Khaynatskaya Yu.Yu., Gordeeva T.A. Analysis of financing expenditures on education in Ukraine. URL: http://intkonf.org/haynatska-yuyu-gordeeva-ta-analizfinansuvannya-vidatkiv-na-osvitu-v-ukrayini

9. Bogolyub T.M. Development of innovative economy and elite education. URL: http://www.disserlib.com 